\title{
Development and evaluation of calcium alginate beads prepared by sequential and simultaneous methods
}

\author{
Sanchita Mandal, S. Senthil Kumar, Balakrishnam Krishnamoorthy, Sanat Kumar Basu*
}

Division of Pharmaceutics, Department of Pharmaceutical Technology, Jadavpur University

\begin{abstract}
The objective of this study was to develop a sustained release dosage form of Trimetazidine dihydrochloride (TMZ) using a natural polymeric carrier prepared in a completely aqueous environment. TMZ was entrapped in calcium alginate beads prepared with sodium alginate by the ionotropic gelation method using calcium chloride as a crosslinking agent. The drug was incorporated either into preformed calcium alginate gel beads (sequential method) or incorporated simultaneously during the gelation stage (simultaneous method). The beads were evaluated for particle size and surface morphology using optical microscopy and SEM, respectively. Beads produced by the sequential method had higher drug entrapment. Drug entrapment in the sequential method was higher with increased $\mathrm{CaCl}_{2}$ and polymer concentration but lower with increased drug concentration. In the simultaneous method, drug entrapment was higher when polymer and drug concentration were increased and also rose to a certain extent with increase in $\mathrm{CaCl}_{2}$ concentration, where further increase resulted in lower drug loading. FTIR studies revealed that there is no interaction between drug and $\mathrm{CaCl}_{2}$. XRD studies showed that the crystalline drug changed to an amorphous state after formulation. Release characteristics of the TMZ loaded calcium alginate beads were studied in enzyme-free simulated gastric and intestinal fluid.
\end{abstract}

Uniterms: Sodium alginate. Calcium alginate beads. Trimetazidine dihydrochloride. Ionotropic gelation.

O objetivo deste estudo foi desenvolver forma de liberação controlada de dicloridrato de trimetazidina (TMZ) utilizando transportador plomérico natural em ambiente completamente aquoso. A TMZ foi presa em pérolas de alginato de cálcio preparadas com alginato de sódio pelo método de gelatinização ionotrópica, usando cloreto de cálcio como agente de formação de ligações cruzadas. O fármaco foi incorporado nas pérolas de gel de alginato de cálcio (método sequencial) ou incorporado, simultaneamente, durante o estágio de gelificação (método simultâneo). As pérolas foram avaliadas quanto ao tamanho das partículas e morfologia da superfície utilizando microscopia óptica de SEM, respectivamente. As pérolas produzidas pelo método sequencial apresentaram maior capacidade de inclusão. No método sequencial, a inclusão de fármaco foi maior com o aumento de $\mathrm{CaCl}_{2}$ e da concentração do plímero, mas menor com o aumento da concentração de fármaco. No método simultâneo, a inclusão de fármaco foi mais alta quando as concentrações de fármaco e plímero foram aumentadas e, também, atingiram certa extensão com aumento na concentração de $\mathrm{CaCl}_{2}$, cujo aumento posterior resultou em carga menor de fármaco. Estudos de FTIR revelaram que não há interação entre fármaco e $\mathrm{CaCl}_{2}$. Estudos de XRD mostraram que o fármaco mudou do estado cristalino para o amorfo após a formulação. As características de liberação de TMZ das pérolas carregadas com alginato de cálcio foram estudadas em fluidos simulados, gástrico e intestinal, livres de enzima.

Uniterms: Alginato de sódio. Beads de alginato de cálcio. Dicloridrato de trimetazidina. Gelatinização ionotrópica.

\section{INTRODUCTION}

TMZ, 1-[(2,3,4-tri-methoxyphenyl) methyl] piperazine is a lesser known member of a new class of antian-

*Correspondence: S. k. Basu. Division of Pharmaceutics, Department of Pharmaceutical Technology, Jadavpur University, Kolkata 700032, India. E-mail: sm_pharm@yahoo.co.in ginal drug (Manchanda, Krishnaswami, 1997). Unlike all the conventional antianginal agents, which affect haemodynamic determinants of the myocardial oxygen supplydemand balance, TMZ partly prevents intercellular metabolic changes such as depletion of adenosine triphosphate (ATP) and phosphocreatine, accumulation of protons, and toxic free radical generation which results from ischemia 
and reperfusion in the myocardium (Harpey et al., 1989). It selectively inhibit long chain 3-keto acyl-co-enzyme A (CoA) thiolase (3-KAT), which catalyses the terminal step of fatty acid beta-oxidation (Stanley, 2002).

Sodium alginate, a hydrophilic biopolymer obtained from brown seaweeds has been found to be highly promising with respect to drug delivery because of its high biological safety (Sriamornsak et al., 2007). Chemically, it is a polysaccharide composed of varying proportions of D-mannuronic acid $(\mathrm{M})$ and L-guluronic acid $(\mathrm{G})$ residues which are arranged in MM or GG blocks interspersed with MG blocks (Aslani, Kennedy, 1996). In addition to its use as a thickening, gel forming and colloidal stabilizing agent in the food and beverage industries, it is also used as a binder in tablet formulation (Liew et al., 2006). Its unique property of forming water insoluble calcium alginate gel through ionotropic gelation with $\mathrm{Ca}^{+2}$ ions under simple and mild conditions has made it possible to encapsulate both macromolecular agents (Polk et al., 1994; Kikuchi et al., 1996; Bowersock et al., 1999) and low molecular weight therapeutic agents (Cui et al., 2001; Gonzalez-Rodriguez et al., 2002; Halder et al., 2005). The current uses of alginate-based devices are mainly related to encapsulation of various classes of therapeutic agents (El-Zatahry et al., 2006, Shishu et al., 2007; Mandal et al., 2010).

In this study, TMZ was incorporated into calcium alginate beads by sequential and simultaneous methods. The effect of polymer and $\mathrm{CaCl}_{2}$ concentration and that of $\mathrm{TMZ}$ concentration on drug entrapment (drug loading) and drug release characteristics were studied. The drug-loaded beads were also characterized using different techniques.

\section{MATERIAL AND METHOD}

Trimetazidine dihydrochloride BP (Sun Pharmaceuticals Pvt. Ltd., Vadodora, India ), Sodium alginate (Fluka) $90 \mathrm{cps}\left(1 \% \mathrm{w} / \mathrm{v}\right.$ solution in water at $\left.25^{\circ} \mathrm{C}\right)$, and Calcium chloride dihydrate (E. Merck, India) were used. All other reagents were of analytical grade.

\section{Preparation of beads}

For bead formation, $50 \mathrm{~mL}$ of a $2-2.5 \% \mathrm{w} / \mathrm{v}$ aqueous solution of sodium alginate was introduced dropwise from a glass syringe with a size- 22 needle into $100 \mathrm{~mL}$ of an aqueous calcium chloride solution being stirred at $400 \mathrm{rpm}$. The concentration of $\mathrm{CaCl}_{2}$ in the solution ranged from $1 \%$ $\mathrm{w} / \mathrm{v}$ to $3 \% \mathrm{w} / \mathrm{v}$. The stirring was continued for one hour and the calcium alginate beads were harvested by filtration, washed with distilled water, and air dried overnight.
Drug loading was carried out by two methods, designated as the sequential method and the simultaneous method. In the sequential method, calcium alginate beads were prepared as described in the previous paragraph. The wet beads were then immersed and stirred for $1 \mathrm{hr}$ in a solution containing TMZ (concentration ranging from 2-3\% w/v), filtered and washed with distilled water. TMZ-loaded calcium alginate beads were obtained by subsequent drying. In the simultaneous method, the gelation of beads by calcium ions occurred simultaneously with the drug loading into the beads. The sodium alginate solution was introduced dropwise into $\mathrm{CaCl}_{2}$ solutions (concentration ranging from 1-3 $\% \mathrm{w} / \mathrm{v}$ ) which also contained TMZ (concentration ranging from $2-3 \% \mathrm{w} / \mathrm{v}$ ). After $1 \mathrm{hr}$ of interaction, the beads were removed from the counter ion solution. The drug loaded beads were washed and dried in a manner similar to that of blank beads (beads without drug).

\section{Determination of drug content}

For determination of drug content, $10 \mathrm{mg}$ of beads were placed in $100 \mathrm{~mL}$ of double distilled water for $24 \mathrm{~h}$. The filtered solution was measured for TMZ content using a UV spectrophotometer (GENESYS 10 UV Spectrophotometer, Thermo Corporation USA) at $202 \mathrm{~nm}$. Drug content was computed using a calibration curve $\left(\mathrm{R}^{2}=0.9998\right)$ prepared using solutions with concentrations of $1-6 \mu \mathrm{g} / \mathrm{mL}$ of TMZ.

The drug loading capacity of the beads was then computed according to the following equation:

Drug Loading $(\%)=\frac{\text { Total amount of drug in particle }}{\text { Weight of particles taken }} \times 100$

\section{Particle size distribution}

The particle size determination of TMZ-loaded calcium alginate beads was carried out using an optical microscope along with a stage micrometer having an accuracy of $0.01 \mathrm{~mm}$. A suspension of beads in liquid paraffin was prepared in a beaker and then one drop of this was dropped on a clean glass slide and covered with a cover slip. The average sizes of 100 beads were determined for each formulation using the calibration factor. The average diameter of the beads was calculated using the following formula:

$$
\mathrm{X}=\frac{\sum\left(\mathrm{X}_{\mathrm{i}}\right)}{\mathrm{N}}
$$

$\mathrm{X}=$ Average particle diameter, $\mathrm{X}_{\mathrm{i}}=$ Individual diameter of beads, $\mathrm{N}=$ Number of beads. 


\section{Scanning electron microscopy}

The surface morphology of drug-loaded beads obtained from various percentages of polymer, $\mathrm{CaCl}_{2}$ and drug were studied by using a scanning electron microscope (model JEOL JSM-6360, Japan). The beads were mounted on an appropriate stub and then coated with carbon and gold (100 and $50 \AA$ thickness respectively) sputter module in a vacuum evaporator in an argon atmosphere. The coated samples were then observed under a scanning electron microscope operated at $15 \mathrm{KV}$.

\section{Fourier transform infra red analysis}

The IR analysis of pure drug, polymer, and drugloaded beads prepared by both the methods were analyzed with FTIR spectrophotometer (Shimadzu FTIR-8400, Japan). All the samples were crushed with potassium bromide to get pellets at $600 \mathrm{~kg} \mathrm{~cm}^{-2}$. Spectral scanning was done in the range of $400-4000 \mathrm{~cm}^{-1}$.

\section{X-ray diffraction study}

To understand the crystalline state of the drug in the polymer matrix, the X-ray diffraction pattern of drugloaded beads was performed and compared with that of pure drug. Powder forms of the samples were exposed to $\mathrm{Cu}$ radiation $(30 \mathrm{kv} \times 15 \mathrm{~mA})$ in a wide-angle $\mathrm{X}$-ray diffractometer (Miniflex gonio Meter, Japan). The instrument was operated in continuous mode in increments of $1 \% \mathrm{~min}$ and scanned over a $2 \Theta$ range of 10 to $90^{\circ}$.

\section{In vitro drug release study}

In vitro drug release studies were carried out in triplicate using a USP II tablet dissolution test apparatus (model TDP-06P, Electro Lab, Mumbai, India) at $37 \pm 0.5^{\circ} \mathrm{C}$ and $100 \mathrm{rpm}$. The beads of each formulation were placed in enzyme-free simulated gastric fluid $(900 \mathrm{~mL}, 0.1 \mathrm{~N} \mathrm{HCl}$, $\mathrm{pH}$ 1.2) for the first $2 \mathrm{~h}$ and then in enzyme-free simulated intestinal fluid $(900 \mathrm{ml}$, Phosphate buffer solution, $\mathrm{pH}$ 6.8) for $7 \mathrm{~h}$. A $5 \mathrm{~mL}$ aliquot of the dissolution fluid was withdrawn at regular intervals of time and replaced immediately with the same volume of fresh media. The aliquots, following suitable dilution, were analyzed for drug content using a spectrophotometer at $202 \mathrm{~nm}$.

\section{RESULTS AND DISCUSSION}

In this investigation, a simple and inexpensive method was developed for the preparation of calcium alginate beads. Crosslinking of sodium alginate was done using $\mathrm{CaCl}_{2}$ and $\mathrm{TMZ}$ was loaded in the same. The various compositions of the formulation variables used for the present study are given in Table I.

TABLE I - Composition of TMZ-loaded calcium alginate beads prepared by sequential and simultaneous method

\begin{tabular}{cccc}
\hline & \multicolumn{3}{c}{ Formulation variables } \\
\cline { 2 - 4 } $\begin{array}{c}\text { Formulation } \\
\text { code }\end{array}$ & $\begin{array}{c}\text { Conc. of } \\
\mathrm{CaCl}_{2} \\
(\% \mathrm{w} / \mathrm{v})\end{array}$ & $\begin{array}{c}\text { Conc. of } \\
\text { sodium } \\
\text { alginate } \\
(\% \mathrm{w} / \mathrm{v})\end{array}$ & $\begin{array}{c}\text { Drug } \\
(\% \mathrm{w} / \mathrm{v})\end{array}$ \\
\hline A1 & 1 & 2 & 2 \\
$\mathrm{~A} 2$ & 1 & 2 & 3 \\
$\mathrm{~A} 3$ & 1 & 2.5 & 2 \\
$\mathrm{~A} 4$ & 1 & 2.5 & 3 \\
$\mathrm{~B} 1$ & 2 & 2 & 2 \\
B2 & 2 & 2 & 3 \\
B3 & 2 & 2.5 & 2 \\
B4 & 2 & 2.5 & 3 \\
C1 & 3 & 2 & 2 \\
C2 & 3 & 2 & 3 \\
C3 & 3 & 2.5 & 2 \\
C4 & 3 & 2.5 & 3 \\
\hline
\end{tabular}

Particle size was in the range of $1005 \mu \mathrm{m}$ to $1075 \mu \mathrm{m}$ for the beads obtained using the sequential method, and $1057 \mu \mathrm{m}$ to $1207 \mu \mathrm{m}$ for those from the simultaneous method (Table 2). The particle size of the beads prepared by the simultaneous method decreased with higher $\mathrm{CaCl}_{2}$ concentrations.

TABLE II - Effect of sodium alginate, $\mathrm{CaCl}_{2}$, and TMZ concentration on particle size and drug loading

\begin{tabular}{ccc}
\hline $\begin{array}{c}\text { Formulation } \\
\text { code }\end{array}$ & $\begin{array}{c}\text { Mean particle size } \\
(\mu \mathrm{m} \pm \mathrm{sd}, \mathrm{n}=3)\end{array}$ & $\begin{array}{c}\text { Drug loading } \\
(\% \pm \mathrm{sd}, \mathrm{n}=3)\end{array}$ \\
\hline \multicolumn{3}{c}{ Sequential method } \\
\hline A3 & $1065 \pm 0.01$ & $53.22 \pm 0.02$ \\
$\mathrm{~B} 3$ & $1060 \pm 0.01$ & $58.15 \pm 0.01$ \\
$\mathrm{C} 2$ & $1057 \pm 0.01$ & $45.21 \pm 0.02$ \\
$\mathrm{C} 3$ & $1005 \pm 0.25$ & $62.15 \pm 0.01$ \\
$\mathrm{C} 4$ & $1075 \pm 0.01$ & $56.28 \pm 0.05$ \\
\hline \multicolumn{3}{|}{ Simultaneous method } \\
\hline A4 & $1207 \pm 0.5$ & $46.89 \pm 0.01$ \\
$\mathrm{~B} 2$ & $1158 \pm 0.75$ & $52.02 \pm 0.03$ \\
$\mathrm{~B} 3$ & $1151 \pm 0.25$ & $55.32 \pm 0.01$ \\
$\mathrm{~B} 4$ & $1106 \pm 0.25$ & $58.28 \pm 0.02$ \\
$\mathrm{C} 4$ & $1057 \pm 0.50$ & $55.60 \pm 0.03$ \\
\hline
\end{tabular}




\section{Scanning electron microscopy}

The surface morphology of the prepared beads was studied by scanning electron microscopy (SEM) and the SEM photographs are depicted in Figure 1.

SEM photographs of the blank beads compared with drug loaded beads show a difference in surface morphology for both the sequential and simultaneous method. Smoothness increased when drug was loaded in the beads.

The SEM photographs of the drug-loaded beads (Figure $1[\mathrm{~A}]$ ) show that the drug is dispersed in the polymeric matrix without having any coat, which further confirms that this system is a polymeric matrix system for beads prepared by both sequential and simultaneous methods.

The SEM photographs presented in Figure 1[B] also show differences in surface morphology of the prepared

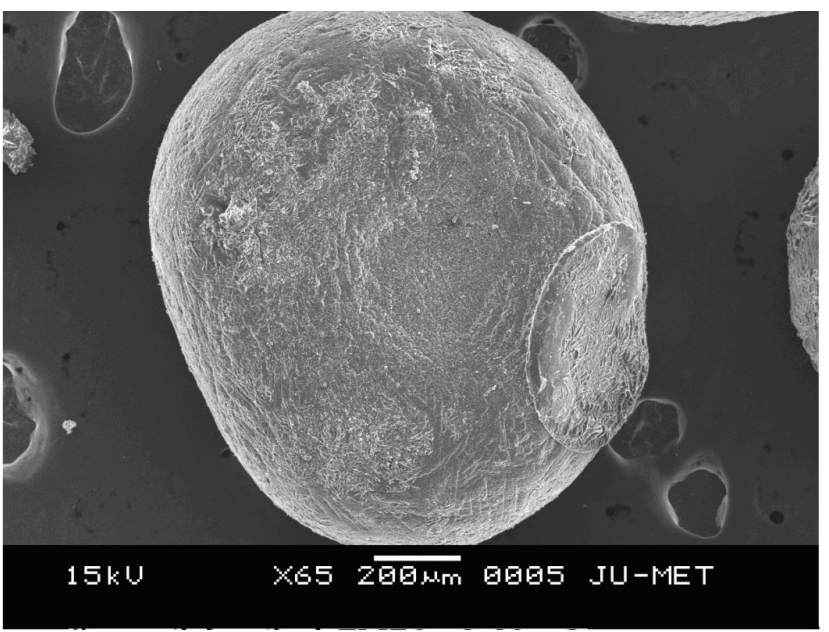

a

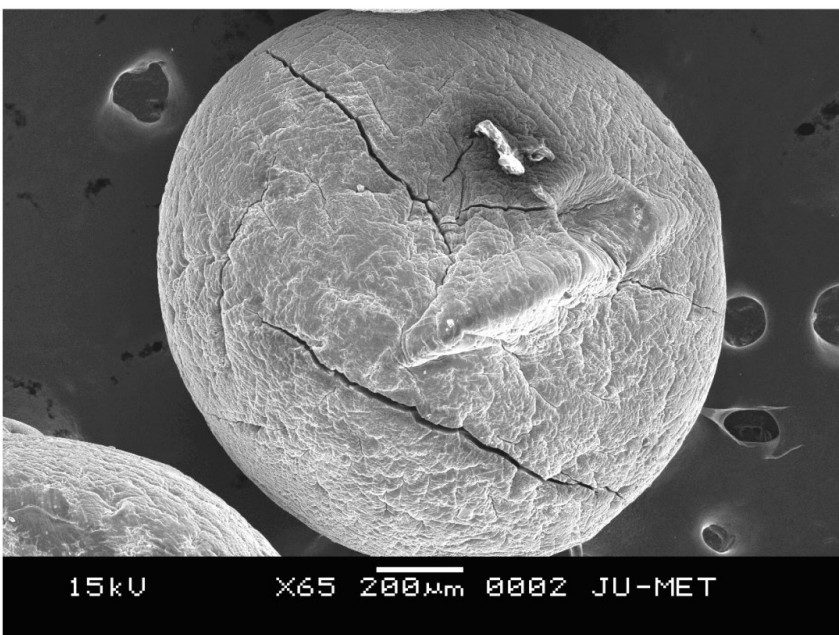

beads before and after the completion of in-vitro dissolution study for both the sequential and simultaneous methods. The surface of beads after dissolution was rougher than before dissolution.

\section{Drug loading}

Drug loading was found to be in the range of 42$62 \%$ for beads prepared by the sequential method and $39-58 \%$ for the simultaneous method. Drug loading was found to be directly proportional to polymer concentration (El-Kamel et al., 2003) in both the methods. The effect of crosslinking agent and drug concentration on drug loading however, was different in both methods.

Higher loading efficiency was obtained as the concentration of alginate increased. This may be attributed to

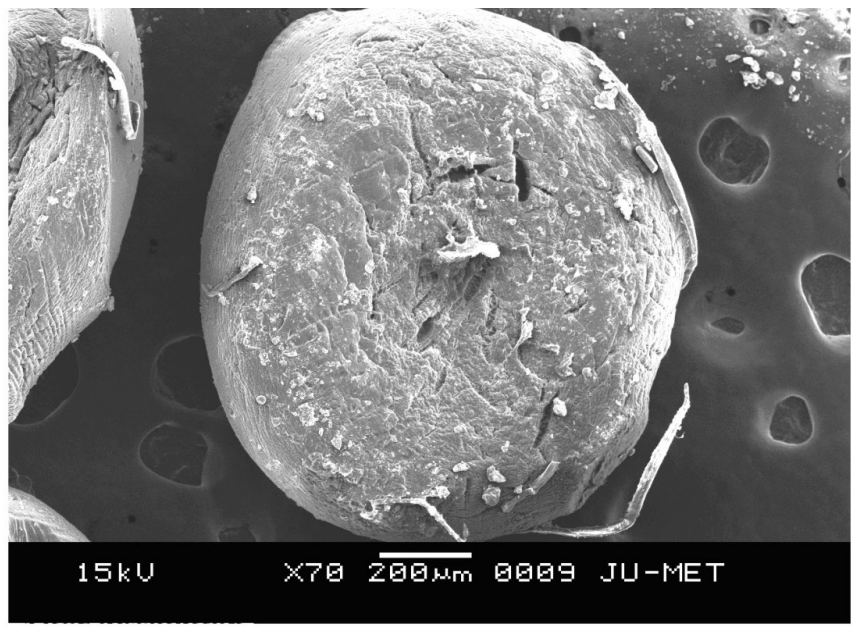

b

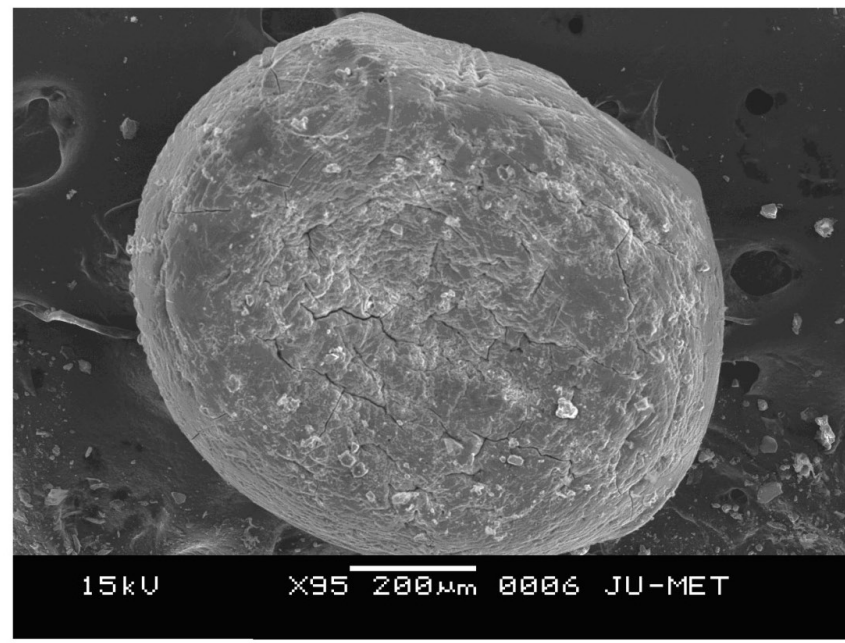

d

FIGURE 1 - [A] SEM photographs of TMZ-loaded calcium alginate beads prepared by the sequential method (a) Drug-loaded bead (b) After dissolution. [B] SEM photographs of TMZ loaded calcium alginate beads prepared by simultaneous method (c) Drug-loaded bead (d) after dissolution. 
the greater availability of active calcium binding sites in the polymeric chains and consequently, the greater degree of crosslinking as the quantity of sodium alginate increased (Yotsuyanagi et al., 1987). For the sequential method, batch $\mathrm{C} 3$ had the highest drug loading $(62 \%)$. The use of drug concentrations greater than $2 \% \mathrm{w} / \mathrm{v}$ did not result in further enhancement of drug loading.

It was observed that the efficiency of loading TMZ into the calcium alginate beads by the simultaneous method was lower than by the sequential method (Lim, Wan, 1997). For the simultaneous method, batch B4 had the highest drug loading (58\%). When the drug loading was carried out by the simultaneous method with the gelation of alginate by $\mathrm{Ca}^{+2}$, the counter ion solution contained both the drug molecule and $\mathrm{CaCl}_{2}$. The drug molecules and $\mathrm{Ca}^{+2}$ ions diffuse in the same direction, from the solution into the sodium alginate solution, and competed simultaneously for common binding sites along the alginate chains. The amount of associated $\mathrm{Ca}^{+2}$ ions (and the drug molecules) in the beads was a function of the concentration ratio of $\mathrm{CaCl}_{2}$ : $\mathrm{TMZ}$ in the solution.
Increase in $\mathrm{CaCl}_{2}$ concentration from 1 to $3 \%$ and polymer concentration from 2 to $2.5 \%$ resulted in an increase in the drug entrapment from $53 \%$ to $62 \%$, and from $45 \%$ to $62 \%$, respectively for the sequential method. Drug entrapment decreased from $62 \%$ to $42 \%$ when the drug concentration was increased from $2-3 \%$ for the same.

Similarly, in the simultaneous method increase in drug entrapment from $47 \%$ to $58 \%$, from $52 \%$ to $58 \%$ and from $55 \%$ to $58 \%$ was observed for corresponding changes in the $\mathrm{CaCl}_{2}$, polymer and drug concentration, respectively.

\section{Fourier transformed infra red analysis}

FTIR spectral data were used to confirm the chemical stability of Trimetazidine in alginate beads. FTIR spectra of pure drug, sodium alginate, TMZ-loaded calcium alginate beads prepared by sequential and simultaneous method were compared in Figure 2. FTIR spectra of TMZ show the characteristic bands of $-\mathrm{OH}$ stretching, $-\mathrm{CH}$ stretching, $>\mathrm{C}=\mathrm{O}$ stretching, $\mathrm{C}-\mathrm{H}$ bending and $\mathrm{C}-\mathrm{O}-$

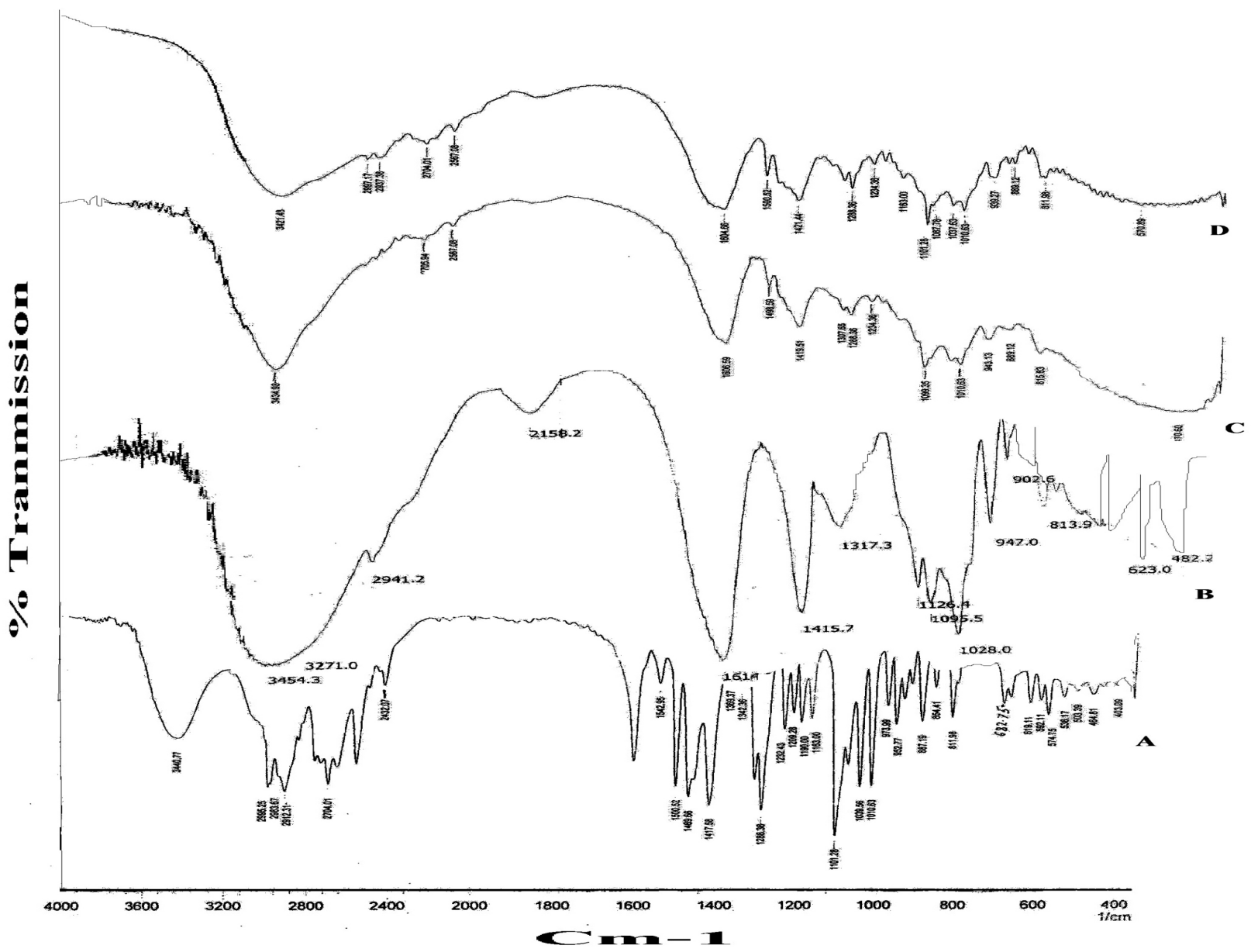

FIGURE 2 - FTIR spectra of TMZ (A), Sodium alginate (B), TMZ-loaded beads prepared by sequential method (C), TMZ loadedbeads prepared by simultaneous method (D). 
C stretching at 3440, 2995, 1605, 1417, and $1101 \mathrm{~cm}^{-1}$, respectively. The spectra obtained from drug-loaded beads prepared by both the methods, indicate the presence of the characteristic bands of the drug at almost the same wave number.

\section{X-ray diffraction study}

In order to confirm the physical state of the drug in the beads, data for the X-ray diffraction studies of the pure drug, polymer, empty beads and beads containing the drug is shown in Figure 3. No characteristic XRD pattern was observed in the case of drug-loaded beads. Thus, from the $\mathrm{X}$-ray diffraction data of the drug-loaded beads, it can be inferred that the drug was not present in the crystalline state in the bead matrix but was in the amorphous state. This clearly indicated that changes in the crystalline state of the drug occurred during the preparation of the beads by this ionotropic gelation method.

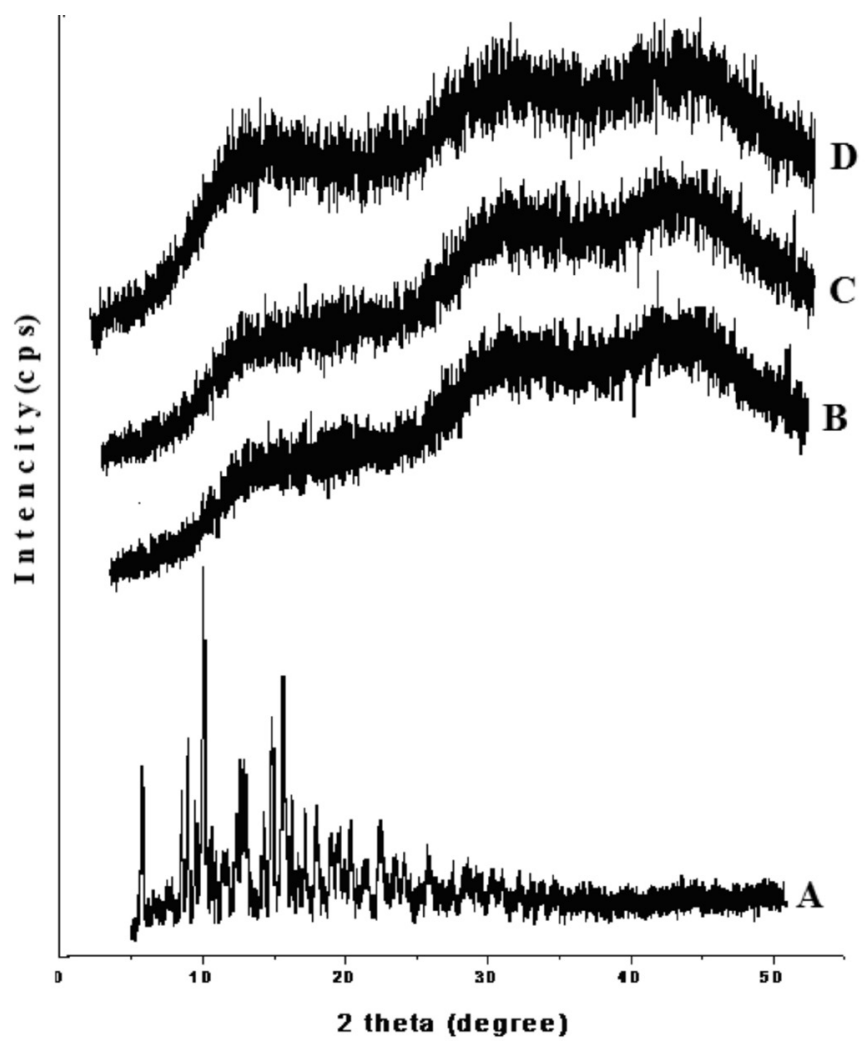

FIGURE 3 - X ray diffractogram of TMZ (A), Sodium alginate (B), TMZ-loaded beads prepared by sequential method(C), TMZ-loaded beads prepared by simultaneous method(D).

\section{In-vitro drug release}

The release profile of TMZ in enzyme-free simulated gastric fluid (SGF) followed by enzyme-free simulated in- testinal fluid (SIF) from the calcium alginate beads prepared under different conditions are shown in Figures 4-6. The drug release from the alginate beads depends on the penetration of the dissolution medium into the beads, swelling and dissolution of alginate matrix, and the dissolution of the drug subsequent to leaching through the swollen matrix. In SGF alginate beads prepared by the sequential method, TMZ releases about 30-40\% drug in the first $2 \mathrm{~h}$. The rest of the drug then releases in the SIF, continuing for up to $9 \mathrm{~h}$ whereby it releases $82-89 \%$ of the drug. It was found that drug release is accompanied by a burst release which may be due to the highly water soluble nature of the drug.
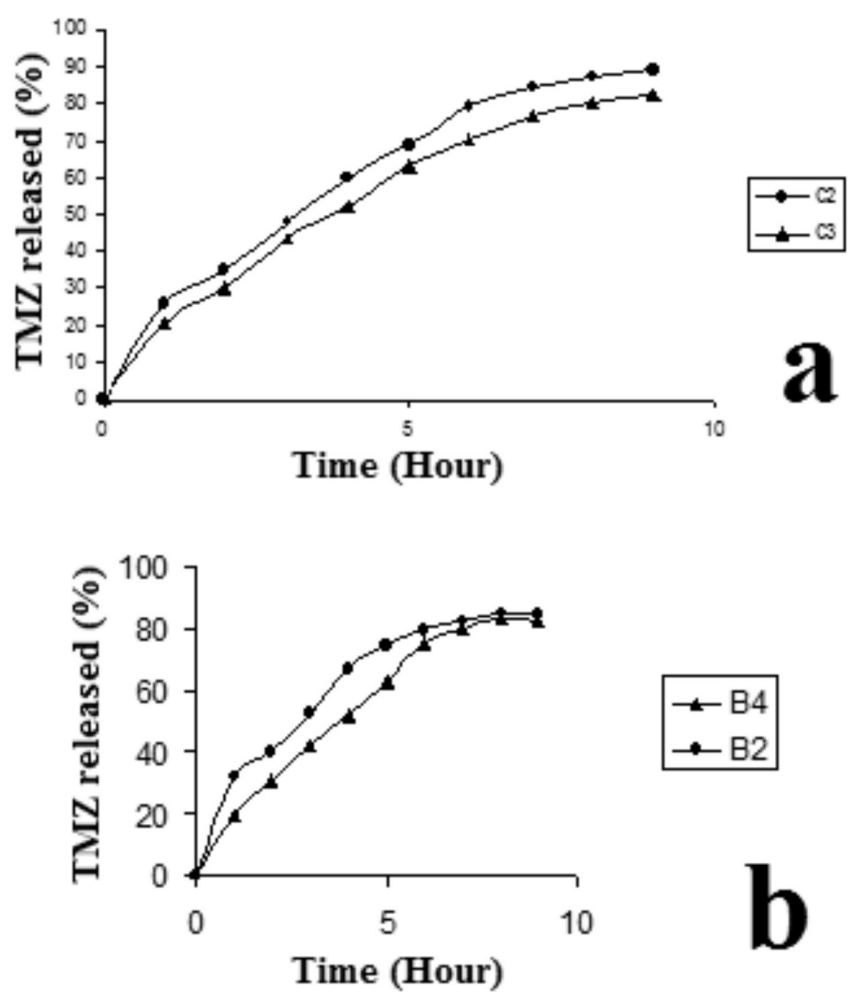

FIGURE 4 - Effect of sodium alginate concentration on TMZ release from calcium alginate beads (a) Sequential method (b) Simultaneous method. (Maximum $\mathrm{SEM} \pm 3.70 \%, \mathrm{n}=4$ ).

\section{Effect of polymer}

To study the effect of sodium alginate concentration on TMZ release, two different concentrations, 2 and $2.5 \% \mathrm{w} / \mathrm{v}$ were used. Figure 4 shows the influence of the concentration of sodium alginate solution on Trimetazidine release behavior from calcium alginate-loaded beads prepared by the sequential and simultaneous methods. Lower concentrations of sodium alginate led to faster drug release, with $89.05 \pm 0.178 \%$ of drug release within 9 h using the sequential method. Increase in alginate concentration slowed the release rate. Thus, the results indicate that 
drug release was directly proportional to sodium alginate concentration (Yotsuyanagi et al., 1987; Basu, Rajendran, 2008). The principal gelation or cross-linking of sodium alginate with $\mathrm{CaCl}_{2}$ is based on the tight junction between the guluronic acid residues (Rajinikanth et al., 2003). The number of the apparent cross-linking points formed within increases with increasing alginate concentration in the formulation. This can be correlated with the particle size studies where, as alginate concentration increased, particle size decreased, due to the formation of more a rigid and compact matrix, consequently retarding TMZ release.

In the case of TMZ-loaded calcium alginate beads prepared by the simultaneous method, similar behavior was also observed.
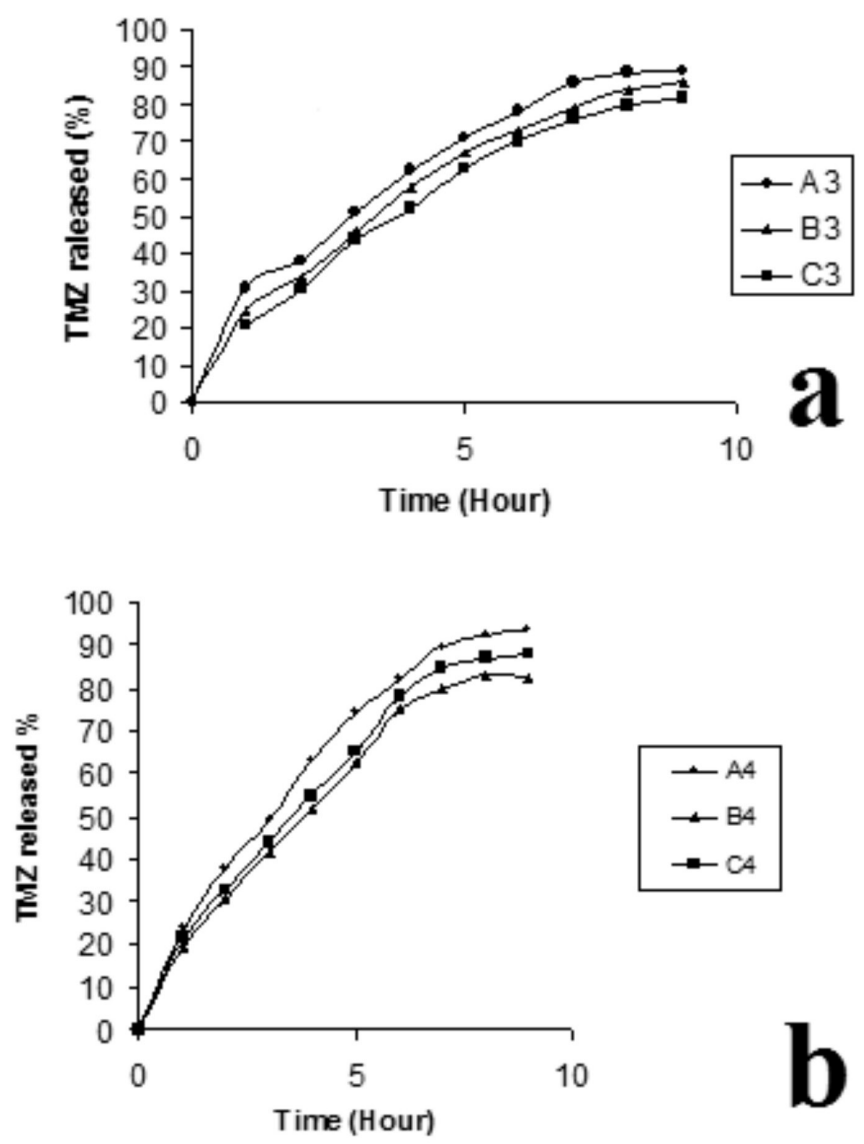

FIGURE 5 - Effect of $\mathrm{CaCl}_{2}$ concentration on TMZ release from calcium alginate beads (a) Sequential method (b) Simultaneous method. (Maximum SEM $\pm 2.50 \%, n=4$ ).

\section{Effect of $\mathrm{CaCl}_{2}$}

The release behavior of calcium alginate beads prepared by the sequential method with different concentrations of $\mathrm{CaCl}_{2}(1-3 \% \mathrm{w} / \mathrm{v})$ is indicated in Figure 5. Drug release was sustained from $38 \%$ to $30 \%$ in SGF for $2 \mathrm{~h}$, and $89 \%$ to $82 \%$ in SIF fluid up to $9 \mathrm{~h}$ with increasing
$\mathrm{CaCl}_{2}$ concentration. Thus, in the sequential method, as the concentration of crosslinking agent increased, drug release decreased (El-Zatahry et al. 2006). Beads prepared with $3 \% \mathrm{w} / \mathrm{v} \mathrm{CaCl}{ }_{2}$ showed the most sustained release effect due to more crosslinking resulting in the formation of a more rigid gel network and hence greater sustained release characteristics. It was confirmed by particle size studies, where the size of the beads was found to be smaller as the concentration of crosslinking agent increased (El-Kamel et al., 2003). It was also evident from the literature (Rajinikanth et al., 2003) that diffusion of drug from alginate matrix decreased as the concentration of $\mathrm{CaCl}_{2}$ solution increased in the sequential method, probably due to greater cross-linking with sodium alginate.

In the simultaneous method, TMZ release was sustained from $30 \%$ to $37 \%$ in SGF for $2 \mathrm{~h}$, and from $93 \%$ to $82 \%$ in SIF up to $9 \mathrm{~h}$ (Figure 5). But in case of the simultaneous method, $3 \%$ crosslinking agent did not show the highest sustained effect. This may be due to the low drug loading (Lim et al., 1997).
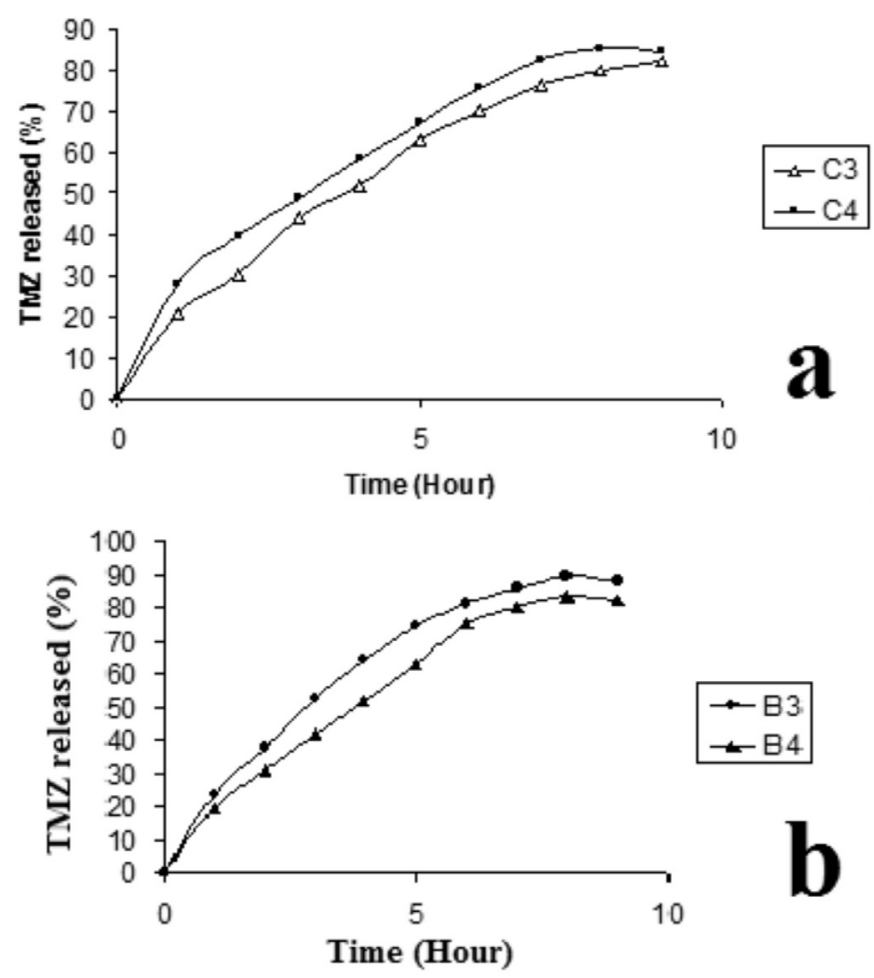

FIGURE 6 - Effect of TMZ concentration on TMZ release from calcium alginate beads (a) Sequential method (b) Simultaneous method. (Maximum SEM $\pm 3.30 \%, n=4$ ).

\section{Effect of drug concentration}

It was found that drug releases within the $1^{\text {st }}$ hour were indicative of a burst effect. This could be attributed 
to the highly water soluble nature of the drug. A similar result was found by Ray et al., (Ray et al., 2008) during preparation of diltiazem resin complex-loaded carboxymethyl xanthan beads.

The effect of drug concentration during in-vitro drug release study does not affect the drug release from the calcium alginate beads. The drug concentration ranged from 2 to $3 \% \mathrm{w} / \mathrm{v}$ to study the effect of drug release shown in Figure 6. TMZ release from beads prepared by the sequential method (batch $\mathrm{C} 3$ ), which contained $2 \% \mathrm{w} / \mathrm{v}$ TMZ, shows a more sustained effect with drug loading of about $62 \%$.

However, in the case of the simultaneous method (batch B4), which contains 3\% w/v drug, a more sustained effect with drug loading of about 58\% was evident. Drug release was found to be highly dependent on drug loading.

\section{CONCLUSION}

Trimetazidine was entrapped in calcium alginate beads prepared with sodium alginate by the ionotropic gelation method, using calcium chloride as a crosslinking agent. The drug was incorporated by two methods, sequential and simultaneous methods. Beads produced by the former method had higher drug entrapment. The beads were evaluated for drug entrapment, particle size and release characteristics in enzyme-free simulated gastric and simulated intestinal fluid. The drug entrapment in the sequential method increases with increased $\mathrm{CaCl}_{2}$ and polymer concentration but decreased with higher drug concentration. In the simultaneous method, drug entrapment was higher with polymer and drug concentration increase and rose to a certain extent with increase in the concentration of $\mathrm{CaCl}_{2}$ and after further increase it decreased. Drug release was directly proportional to the polymer concentration for the drug-loaded beads prepared by both the methods. Increase in $\mathrm{CaCl}_{2}$ concentration retarded the drug release in the sequential method whereas for the simultaneous method the retardation in drug release occurred up to a certain concentration of $\mathrm{CaCl}_{2}$. The drug concentration exhibits a drug-loading dependent effect on the release behavior in both the methods.

\section{ACKNOWLEDGEMENT}

The authors would like to thank Sun Pharmaceuticals Pvt Ltd, Vadodora, India for supplying Trimetazidine dihydrochloride as a gift sample.

\section{REFERENCES}

ASLANI, P.; KENNEDY, R.A. Studies on diffusion in alginate gels, I. Effects of cross-linking with calcium or zinc ions on diffusion of acetaminophen. J. Control. Rel, v.42, p.75$82,1996$.

BASU, S.K.; RAJENDRAN, A. Studies in the development of neteglinide loaded calcium alginate and chitosan coated calcium alginate beads. Chem. Pharm. Bull., v.56, p.10771084, 2008.

BOWERSOCK, T.L; HOGE.; ESCH, H.; SUCKOW, M.; GUIMOND, P.; MARTIN, S.; BORIE, D. Oral vaccination of animals with antigens encapsulated in alginate Microspheres. Vaccine, v.17, p.1804-1811, 1999.

CUI, J.H.; GOH, J.S.; PARK, S.Y.; KIM, P.H.; LE, B.J. Preparation and physical characterization of alginate microparticles using air atomization method. Drug. Dev. Ind. Pharm, v.27, p.309-319, 2001.

EL-ZATAHRY, A.A.; SOLIMAN, E.A.; HASSAN, E.A.; MOHY ELDIN, M.S. Preparation and in vitro release of theophylline loaded sodium alginate microspheres. In: ASTF. SCIENTIFIC RESEARCH OUTLOOK 2006 CONFERENCE. Paper n.155, p.1-20, 2006. <http:// www.astf.net/sro/sro4/third $\% 20$ scope $\% 20$ priorities $\% 20$ of $\% 20$ scientific $\% 20$ research $\% 20$ and $\% 20$ specialized $\% 20$ domains $\% 20$ in $\% 20$ science/Scientific $\% 20$ areas $\% 20$ of $\% 20$ priorities/New\%20Material/Accepted/155P.pdf $>$. Accessed on: $28^{\text {th }}$ feb. 2006

EL-KAMEL, A.H.; AL-GOHARY, O.M.; HOSNY, E.A. Alginate-diltiazem hydrochloride beads: optimization of formulations factors, in vitro and in vivo availability. $J$. Microencapsul., v.20, p.211-225, 2003.

GONZALEZ-RODRIGUEZ, M.L.; HOLGADO, M.A.; SANCHEZ-LAFUENTE, C.; RABASCO, A.M.; FINI, A. Alginate/Chitosan particulate systems for sodium Diclofenac release. Int. J. Pharm., v.232, p.225-234, 2002.

HALDER, A.; MAITI, S.; SA, B. Entrapment efficiency and release characteristics of polyethyleneimine-treated oruntreated calcium alginate beads loaded with propranololresign complex. Int. J. Pharm., v.302, p.84-94, 2005.

HARPEY, C.; CLAUSER, P.; LABRID, C.; FRYRIA, J-L.; POIRIER, J-P. Trimetazidine, a cellular anti-ischemic agent. Cardiovasc. Drugs Rev., v.6, p.292-312, 1988. 
KIKUCHI, A.; KAWABUCHI, M.; SUGIHARA, M.; SAKURAI, Y.; OKANO, T. Controlled release of macromolecular dextran from calcium-alginate gel beads. Control. Rel. Bioact. Mater, v.23, p.737-738, 1996.

LIEW, C.V.; CHAN, L.W.; CHING, A.L.; HENG, P.W.S. Evaluation of Sodium alginate as drug release modifier in matrix tablets. Int. J. Pharm., v.309, p.25-37, 2006.

LIM, L.Y.; WAN, S.C. Propanolol hydrochloride binding in calcium alginate beads. Drug Dev. Ind. Pharm., v.23, p.973-980, 1997.

MANCHANDA, S.C.; KRISHNASWAMI, S. Combination treatment with Trimetazidine and diltiazem in stable angina pectoris. Heart, v.78, p.353-357, 1997.

MANDAL, B.; ALEXANDER, K.S.; RIGA, A.T. Evaluation of the drug-polymer interaction in calcium alginate beads containing diflunisal. Pharmazie, v.65, p.106-109, 2010.

POLK, A.; AMSDEN, B.; YAO, K.D.; PENG, T.; GOOSEN, M.F.A. Controlled release of albumin from chitosanalginate microcapsules. J. Pharm. Sci., v.83, p.178-185, 1994.

RAJINIKANTH, P.S.; SANKAR, C.; MISHRA, B. Sodium alginate microsphere of metoprolol tartarate for intranasal systemic delivery: development and evaluation. Drug Deliv., v.10, p.21-28, 2003.
RAY, S.; MAITI, S.; SA, B. Preliminary investigation on the development of diltiazem resign complex loaded carboxymethyl xanthan beads. AAPS PharmSciTech., v.9, p.295-299, 2008.

SHISHU, GUPTA, N.; AGGARWAL, N. Stomach-specific drug delivery of 5-fluorouracil using floating alginate beads. AAPS PharmSciTech., v.8, p.E1-E7, 2007.

STANLEY, W.C. Partial inhibition of cardiac fatty acid oxidation for the treatment of chronic stable angina. Expert Opin. Invest. Drugs, v.11, p.1-15, 2002.

SRIAMORNSAK, P.; THIRAWONG, N.; KORKERD, K. Swelling, erosion and release behaviour of alginate-based matrix tablets. Eur. J. Pharm. Biopharm., v.66, p.435-450, 2007.

YOTSUYANAGI, T.; OHKUBO, T.; OHHASHI, T.; IKEDA, K. Calcium-induced gelatin of alginic acid and $\mathrm{pH}$-sensitive reswelling of dried gels. Chem. Pharm. Bull., v.35, p.1555$1563,1987$.

Received for publication on $23^{\text {th }}$ November 2009. Accepted for publication on $17^{\text {th }}$ March 2010. 